\title{
PERANCANGAN DISPLAY INFORMASI KETERSEDIAAN BLANKO KTP ELEKTRONIK DINAS DUKCAPIL KABUPATEN LOMBOK TIMUR
}

\author{
(DESIGN OF INFORMATION DISPLAY AVAILABILITY OF ELECTRONIC POPULATION \\ SIGN CARD BLANKS DEPARTMENT OF POPULATION AND CIVIL REGISTRATION OF \\ EAST LOMBOK DISTRICT)
}

\author{
Sri Handriana Dewi Hastuti ${ }^{1)}$ \\ ${ }^{1)}$ STMIK Syaikh Zainuddin NW Anjani \\ 3) \\ ${ }^{1)}$ e-mail: penulis.pertama@email.com ${ }^{1)}$
}

\begin{abstract}
ABSTRAK
Kebutuhan informasi semakin tinggi pada era teknologi yang semakin berkembang. Penyampaian informasi yang cepat dan aktual menjadi suatu tantangan tersendiri dalam mengembangkan suatu teknologi informasi. Salah satu jenis pelayanan publik yang merupakan kewajiban pemerintah dan memiliki peran strategis adalah pelayanan publik di bidang kependudukan dan pencatatan sipil. Masyarakat kadang dibuat kecewa saat ingin mendapatkan pelayanan administrasi kependudukan khususnya KTP Elektronik. Dengan tidak diumumkannya ketersediaan stok blangko fisik KTP-el bisa dimanfaatkan oleh oknum calo dalam mengurus adminduk. Dengan dalih blangko fisik KTP-el habis, sehingga dapat dijadikan momen bagi oknum calo dalam mencari keuntungan dalam pengurusan adminduk. Dengan adanya Display Informasi Blangko KTP elektonik ini, maka diharapkn masyarakat memperoleh keterbukaan informasi mengenai blangko KTP Elektronik yang tersedia.
\end{abstract}

Kata Kunci: KTP, Balanko, Informasi.

\section{ABSTRACT}

The need for information is increasingly high in the era of growing technology. The delivery of information quickly and actual becomes a challenge in developing an information technology. One type of public service that is the government's obligation and has a strategic role is public services in the field of population and civil registration. People are sometimes disappointed when they want to get population administration services, especially Electronic Identity Cards. By not announcing the availability of physical blank stocks of Electronic Identity Cards, intermediaries can use them in managing population administration. On the pretext that the physical blank of the Electronic Identity Card is used up, so that it can be used as a moment for intermediary individuals to seek profits in managing population administration. With this electronic Blank Information Display, it is hoped that the public will obtain information disclosure regarding available blank Electronic Identity Cards.

Keywords: KTP, Blanko, Information.

\section{Pendahuluan}

elayanan publik (public service) merupakan

$\mathrm{P}$ salah satu perwujudan dari fungsi pada aparatur negara sebagai abdi masyarakat, pelayanan publik dimaksudkan untuk mensejahterakan masyarakat atau warga negara. Pelayanan publik yang profesional, itu artinya pelayanan publik yang bercirikan oleh adanya akuntabilitas dan responsibilitas dari pemberi layanan (aparatur pemerintah)[1].
Good governance merupakan isu sentral yang paling mengemuka dalam pengelolaan administrasi publik dewasa ini. Tuntutan gencar yang dilakukan oleh masyarakat kepada pemerintah untuk melaksanakan penyelenggaraan pemerintahan yang baik adalah sejalan dengan meningkatnya tingkat pengetahuan dan pendidikan masyarakat, selain adanya pengaruh globalisasi. Pola lama penyelenggaraan pemerintah kini sudah tidak sesuai lagi dengan tatanan masyarakat yang telah berubah. Oleh karena itu, tuntutan ini merupakan hal yang 
wajar dan sudah seharusnya direspon oleh pemerintah dengan melakukan perubahan yang terarah pada terwujudnya penyelenggaraan good governance (Sedarmayanti,2004:4).[3]

Salah satu jenis pelayanan publik yang merupakan kewajiban pemerintah dan memiliki peran strategis adalah pelayanan publik di bidang kependudukan dan pencatatan sipil. Salah satunya adalah pelayanan Kartu Tanda Penduduk Elektronik. Informasi yang ditemukan secara langsung dan melalui berbagai media massa baik cetak maupun Elektronik seringkali mengungkapkan berbagai kelemahan pelayanan pemerintah yang mencerminkan ketidak puasan masyarakat terhadap pelayanan tersebut.[2]

Selama ini masyarakat kadang dibuat kecewa saat ingin mendapatkan pelayanan adminduk khususnya KTP Elektronik, karena jauh jauh datang ke UPT di kecamatan, sering mendapati informasi dari petugas soal kekosongan blangko dan lain lainnya. Dengan tidak diumumkannya ketersediaan stok blangko fisik KTP-el bisa dimanfaatkan oleh oknum calo dalam mengurus adminduk. Dengan dalih blangko fisik KTP-el habis, sehingga dapat dijadikan momen bagi oknum calo dalam mencari keuntungan dalam pengurusan adminduk.

Berdasarkan latar belakang diatas, maka penulis tertarik melakukan penelitian untuk melakukan Perancangan Display Informasi Ketersediaan Blangko KTP Elektronik.

\section{STUDI PUSTAKA}

Penelitian sejenis dilakukan oleh Revy Zunitha Nasution (2018)[4] yang berjudul " Akuntabilitas Pelayanan KTP Elektronik (KTP El) Di Dinas Kependudukan dan Catatan Sipil Kota Medan". Hasil penelitian tersebut menunjukkan bahwa Pelayanan KTP Elektronik di Dinas Kependudukan dan Catatan Sipil Kota Medan cukup akuntabel dari segi profesionalitas pegawai dan kejelasan pelayanan.

Penelitian selanjutnya dilakukan oleh A. Kholidi (2015)[5] yang berjudul " Pelayanan KTP El di Dinas Kependudukan dan Pencatatan Sipil Kabupaten Tanjung Jabung Barat". Hasil penelitian tersebut menunjukkan bahwa pelayanan KTP El di Dinas Kependudukan dan Pencatatan Sipil Kabupaten Tanjung Jabung Barat belum baik karena adanya faktor struktur organisasi, kemampuan aparat dan sistem pelayanan.

\section{METODE PENELITIAN}

Teknik pengumpulan data merupakan suatu cara memperoleh data-data yang diperlukan dalam penelitian. Dalam penelitian ini teknik yang digunakan antara lain sebagai berikut:

1. Observasi, merupakan aktivitas penelitian dalam rangka mengumpulkan data yang berkaitan dengan masalah penelitian melalui proses pengamatan langsung di lapangan.

2. Wawancara (interview), adalah percakapan dengan maksud tertentu. Melalui wawancara inilah peneliti menggali data, informasi, dan kerangka keterangan dari subyek penelitian. Teknik wawancara yang dilakukan adalah wawancara bebas terpimpin, artinya pertanyaan yang dilontarkan tidak terpaku pada pedoman wawancara dan dapat diperdalam maupun dikembangkan sesuai dengan situasi dan kondisi lapangan. Usecase diagram.

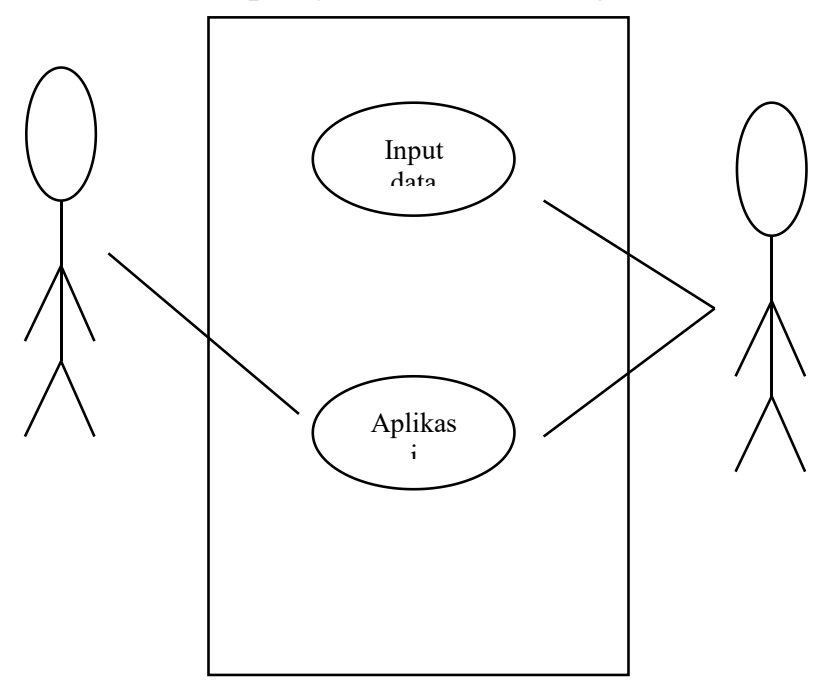

Gambar 1. Usecase Diagram

\section{HASIL DAN PEMBAHASAN}

Dinas Kependudukan dan Pencatatan Sipil Kabupaten Lombok Timur saat ini memiliki 10 Unit Pelaksana Teknis (UPT).

Adapun UPT tersebut adalah sebagai berikut :

1. UPT Wilayah I, bertempat di Kecamatan Suela dengan wilayah Kecamatan Suela dan Sembalun.

2. UPT Wilayah II, bertempat di Kecamatan Pringgabaya dengan wilayah Kecamatan Pringgabaya dan Sambelia 
3. UPT Wilayah III, bertempat di Kecamatan Aikmel dengan wilayah Kecamatan Aikmel, Wanasaba dan Lenek.

4. UPT Wilayah IV, bertempat di Kecamatan Sukamulia dengan wilayah Kecamatan Sukamulia dan Suralaga.

5. UPT Wilayah V, bertempat di Kecamatan Selong dengan wilayah Kecamatan Selong dan Labuhan Haji.

6. UPT Wilayah VI, bertempat di Kecamatan Masbagik dengan wilayah Kecamatan Masbagik dan Pringgasela.

7. UPT Wilayah VII, bertempat di Kecamatan Sikur dengan wilayah Kecamatan Sikur.

8. UPT Wilayah VIII, bertempat di Kecamatan Terara dengan wilayah Kecamatan Terara dan Montong Gading.

9. UPT Wilayah IX, bertempat di Kecamatan Keruak dengan wilayah Kecamatan Keruak dan Jerowaru.

10. UPT Wilayah X, bertempat di Kecamatan Sakra dengan wilayah Kecamatan Sakra, Sakra Barat dan Sakra Timur.

Display informasi ini akan menampilkan keadaan blangko KTP el di masing-masing UPT . Karena aplikasi ini berbasis web, maka memungkinkan administrator dapat mengupdate kapan saja dan dimana saja.

Berikut ini adalah rancangan tampilan dari Display Informasi Ketersediaan Blangko KTP Elektronik yang ada di masing-masing UPT Dinas Dukcapil Kabupaten Lombok Timur.

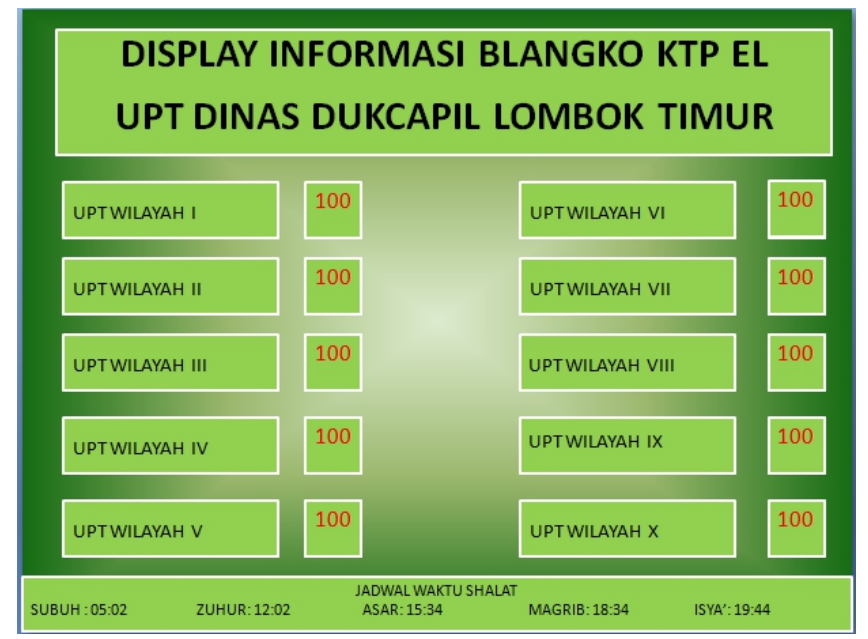

Pada gambar diatas, terlihat bahwa pada hari tersebut pada masing-masing UPT ( Unit Pelaksana Teknis) tersedia 100 keping blanko, sehingga masyarakat langsung mendapatkan informasi jumlah blanko yang tersedia hari itu. Dengan adanya Display Informasi Blangko KTP elektonik ini, maka diharapkan masyarakat memperoleh keterbukaan informasi mengenai blangko KTP Elektronik yang tersedia sehingga paling tidak meminimalisir terjadinya praktik percaloan KTP.

\section{Kesimpulan}

Berdasarkan penelitian yang dilakukan bahwa salah satu cara dalam rangka prinsip keterbukaan informasi terhadap masyarakat mengenai ketersediaan blangko KTP Elektronik adalah dengan membuat suatu aplikasi yang dapat menampilkan jumlah ketersediaan blangko di Dinas Kependudukan dan Pencatatan Sipil Kabupaten Lombok Timur khususnya UPT (Unit Pelaksana Teknis Dinas) yang tersebar di kecamatan yang ada di Kabupaten Lombok Timur.

\section{DAFTAR PUSTAKA}

[1] Setiawan, M, "Kualitas Pelayanan Pembuatan Kartu Keluarga pada Dinas Kependudukan dan Catatan Sipil Kabupaten Bandung”, Thesis, Dept. Administrasi Negara, Univ. Pasundang Bandung, 2016.

[2] Holidi, A, "Pelayanan KTP-eL di Dinas Kependudukan dan Pencatatan Sipil di Kabupaten Tanjung Jabung Barat", Tesis, Universitas Terbuka, Jakarta, 2015.

[3] Nasution, Revi Zunitha, "Akuntabilitas dalam Pelayanan KPT Elektronik (KTP-El) di Dinas Kependudukan dan Catatan Sipil Kota Medan, Skripsi, Dept. Ilmu Administrasi Negera, Univ. Sumatera Utara, Medan, 2017.

[4] Listiana, Sulistyowati, "Partisipasi Masyarakat pada Pelestarian Tradisi Suran Mbah Demang sebagai Kearifan Lokal di Modinan, Banyuraden, Gamping, Sleman", Thesis, Dept. Ilmu Sosial, Univ. Negeri Yogyakarta, 2013.

[5] Catur Nugraheni Puspita Dewi, dkk. Analisa dan Perancangan Sistem Papan Informasi Elekronik Terintegrasi di Universitas. Jurnal TI Atma Luhur Vol 4. No 1. September 2017.

[6] Peraturan Bupati Nomor 11 tahun2019 tentang Pembentukan, Susunan Organisasi, Tata Kerja Unit Pelaksana Teknis Dinas Kependudukan dan Pencatatn Sipil Kabupaten Lombok Timur. 